\title{
IDEOLOGI SEKULARISME DALAM KOMENTAR MASYARAKAT TENTANG WACANA PILKADA DKI JAKARTA DI MEDIA SOSIAL
}

\author{
Liza Halimatul Humairah, Agustina Agustina, Ngusman Abdul Manaf \\ Program Studi Magister Pendidikan Bahasa Indonesia, Universitas Negeri Padang \\ Jalan Prof. Dokter Hamka, Air Tawar Barat, Padang, Sumatera Barat. \\ Surel: Liza.halimatulhumairah@yahoo.com
}

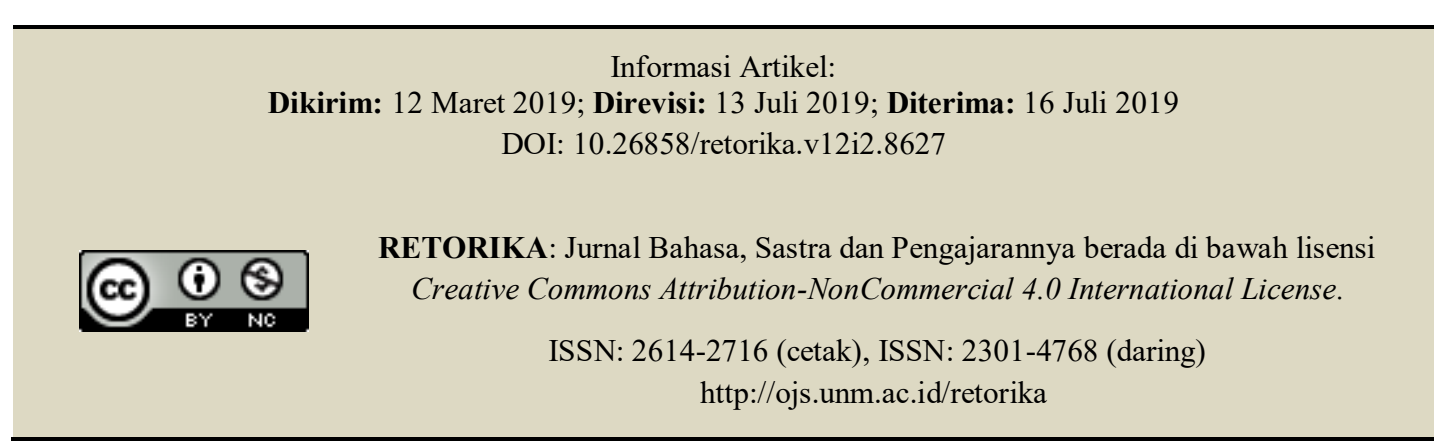

\begin{abstract}
The Ideology of Secularism in the Public Comment on the Discourse of DKI Jakarta Pilkada on Social Media. This study aims to determine the realization of secularism in the public comment text on the DKI Jakarta Pilkada news discourse on social media in terms of vocabulary and sentence structure. This study uses a qualitative-descriptive approach and content analysis method based on Norman Fairclough's theory of critical discourse. The results of the study show that the ideology of secularism is realized: (1) using words that are not related to religion such as the words smart, objective, rational, not, real work etc. which is associated with context; (2) active sentences, with the aim of further highlighting the actors and objects of events; and (3) passive sentences, with the aim of further highlighting the target and hiding the perpetrator. Ideology in discourse can be expressed through vocabulary choices and sentence structure in text through critical discourse analysis, both in mass media texts, and in individual texts (comments) on social media.
\end{abstract}

Keywords: ideology, comments of community, regional election discourse, secularism

\begin{abstract}
Abstrak: Ideologi Sekularisme dalam Komentar Masyarakat tentang Wacana Pilkada DKI Jakarta di Media Sosial. Penelitian ini bertujuan untuk menentukan realisasi sekularisme dalam teks komentar masyarakat terhadap wacana berita Pilkada DKI Jakarta di media sosial dari segi kosakata dan struktur kalimat. Penelitian ini menggunakan pendekatan kualitatif-deskriptif dan metode content analysis berdasarkan teori analisis wacana kritis Norman Fairclough. Hasil penelitian menunjukkan bahwa ideologi sekularisme direalisasikan: (1) menggunakan kata yang tidak berkaitan dengan agama seperti kata cerdas, objektif, rasional, jangan, kerja nyata dsb. yang dikaitkan dengan konteks; (2) kalimat aktif, dengan tujuan lebih menonjolkan pelaku dan objek peristiwa; dan (3) kalimat pasif, dengan tujuan lebih menonjolkan sasaran dan menyembunyikan pelaku. Ideologi dalam wacana dapat diungkapkan melalui pilihan kosakata dan struktur kalimat dalam teks melalui analisis wacana kritis, baik dalam teks media massa, maupun dalam teks (komentar) individu di media sosial.
\end{abstract}

Kata kunci: ideologi, komentar masyarakat, wacana pilkada, sekularisme 
Komentar masyarakat terhadap wacana politik Pilkada penting untuk diteliti karena setiap pemilihan kepala daerah tidak bisa terlepas dari masyarakat yang memilihnya (Usfinifit, Suprojo, dan Setyawan, 2014). Masyarakat tidak hanya sekadar berkomentar, tetapi ada ideologi atau maksud dan tujuan tertentu.

Ideologi dan bahasa ibarat dua sisi mata uang (Widyawari \& Zulaeha, 2016). Kedua istilah tersebut tidak dapat dipisahkan satu sama lain. Bahasa digunakan untuk merepresentasikan ideologi dan ideologi dapat dipahami melalui penggunaan bahasa (Abdunasir, 2015; Shahsavar 2015; Faris \& Paramasivam, 2016; dan Ramanathan \& Hoon, 2016). Begitu juga dengan komentar masyarakat terhadap wacana berita Pilkada DKI Jakarta. Teks komentar masyarakat juga tidak akan pernah lepas dari ideologi tertentu (Widyawari \& Zulaeha, 2016).

Penelitian tentang ideologi dalam sebuah teks sudah banyak dilakukan oleh peneliti terdahulu, misalnya, oleh Bukhari \& Xiaoyang (2013) di Cina, Ahmed (2014) di Pakistan, Sideeg (2015) di Australia, Faris \& Paramasivam (2016) di Mandela, Ramanathan \& Hoon (2016) di Malaysia, dan Mohammadi (2017) di Iran. Berdasarkan penelitian tersebut, diketahui bahwa terdapat ideologi yang tersembunyi di dalam teks wacana. Hal tersebut dapat diketahui dan ditelusuri melalui analisis wacana kritis. Meskipun sudah banyak peneliti yang mengkaji tentang ideologi, namun belum ada satupun peneliti yang khusus mengkaji ideologi sekularisme dalam komentar masyarakat terhadap wacana berita Pilkada DKI Jakarta di media sosial. Selama ini, peneliti sebelumnya banyak meneliti ideologi wartawan dan media pada saat menulis teks. Pembaharuan penelitian yang dilakukan adalah peneliti melihat ideologi masingmasing masyarakat yang bersifat personal sebagai pembaca berita yang diungkapkan melalui komentar terhadap berita politik tersebut.

Ideologi merupakan rumusan alam pikiran yang terdapat di berbagai subjek atau kelompok masyarakat yang ada, dijadikan dasar untuk direalisasikan. Ideologi tidak hanya dimiliki oleh negara, tetapi dapat juga berupa keyakinan yang dimiliki oleh suatu organisasi dalam negara, seperti partai politik dan individu (Syam, 2010: 238).

Menurut Eriyanto (2009: 87-88), istilah ideologi digunakan dalam arti yang berbeda- beda. Secara positif, ideologi dipersepsikan sebagai suatu pandangan dunia (worldview) yang menyatakan nilai-nilai kelompok sosial tertentu untuk membela dan memajukan kepentingankepentingan mereka. Secara negatif, ideologi dilihat sebagai suatu kesadaran palsu, yaitu suatu kebutuhan untuk melakukan penipuan dengan cara memutarbalikkan pemahaman orang mengenai realitas sosial.

Istilah ideologi dipergunakan dalam banyak arti, namun pada hakikatnya semua arti tersebut dapat dikembalikan pada satu di antara atau kombinasi dari tiga arti, yaitu (1) ideologi sebagai kesadaran palsu, (2) ideologi dalam arti netral, dan (3) ideologi dalam arti keyakinan yang tidak ilmiah (Sobur, 2006: 66-68). Selanjutnya, ideologi secara lebih luas dikemukakan oleh sejumlah pemikir dan ilmuan maupun tokoh pergerakan politik. Alfian, seorang ilmuan politik di Indonesia mengemukakan bahwa ideologi adalah pandangan atau sistem nilai yang menyeluruh dan mendalam yang dipunyai dan dipegang oleh suatu masyarakat tentang bagaimana cara yang sebaiknya, yaitu secara moral dianggap benar dan adil, mengatur tingkah laku mereka bersama dalam berbagai segi kehidupan duniawi mereka (Syam, 2010: 239). Selanjutnya, Sukarni, seorang ilmuwan politik juga mengemukakan bahwa ideologi adalah konsepsi manusia mengenai politik, sosial, ekonomi, dan kebudayaan untuk diterapkan di dalam masyarakat atau negara (Syam, 2010: 239).

Berdasarkan pendapat para ahli tersebut, dapat disimpulkan bahwa ideologi adalah pandangan yang mendalam yang dipegang dan dimiliki oleh individu atau kelompok mengenai politik, sosial, ekonomi, dan kebudayaan yang diterapkan di dalam kehidupan untuk mengatur masalah tindakan dan praktik individu atau anggota suatu kelompok tersebut.

Salah satu jenis ideologi adalah sekularisme. Sekularisme secara bahasa bisa diartikan sebagai faham yang hanya melihat kepada kehidupan saat ini saja dan di dunia ini tanpa ada perhatian kepada hal-hal yang bersifat spiritual seperti adanya kehidupan setelah kematian yang notabene adalah inti dari ajaran agama (Hurd, 2004; Tiwary, 2017). Secara terminologi, sekularisme didefinisikan sebagai sebuah konsep yang memisahkan antara negara (politik) dan agama (state and religion). Negara merupakan lembaga yang mengurusi tatanan hidup yang bersifat duniawi dan tidak ada hubungannya 
dengan yang berbau akhirat, sedangkan agama adalah lembaga yang hanya mengatur hubungan manusia dengan hal-hal yang bersifat metafisis dan bersifat spiritual, seperti hubungan manusia dengan Tuhan. Menurut para sekular, negara dan agama yang dianggap mempunyai kutub yang berbeda tidak bisa disatukan. Masing-masing haruslah berada pada jalurnya sendiri-sendiri.

Berdasarkan pendapat tersebut, disimpulkan bahwa sekularisme adalah suatu paham atau kepercayaan yang menganggap bahwa agama tidak boleh diikursertakan ke dalam urusan pemerintahan (politik, negara, atau institusi publik). Dengan kata lain, sekularisme merujuk kepada kepercayaan bahwa semua kegiatan dan keputusan yang keseluruhannya berada dan dibuat oleh manusia, tidak boleh ada peran dan campur tangan agama di dalamnya.

Akhir-akhir ini banyak masyarakat yang mengaitkan paham sekularisme pada saat memilih pemimpin, baik pemimpin daerah maupun negara. Paham sekularisme memisahkan antara agama dengan sistem pemerintahan (Altwajri, 1997: 120; Abdulsyani, 2012: 178; Susanto, 2013: 41). Bagi masyarakat sekular, kedua hal tersebut adalah dua hal yang saling berbeda dan tidak dapat dicampurkanadukan dan agama tidak penting dikaitkan pada saat memilih pemimpin. Untuk mengungkapkan ideologi yang tersembunyi dalam teks komentar masyarakat terhadap wacana politik Pilkada DKI Jakarta, di dalam kajian linguistik, dilakukan melalui analisis wacana kritis (Vahid, 2012; Bukhari \& Xiaoyang, 2013; Asghar, 2014; dan Ali \& Nordin, 2016).

Dalam penelitian ini, wacana politik dipilih sebagai sumber objek penelitian karena pada awal tahun 2017, wacana berita Pilkada DKI Jakarta menjadi topik pembicaraan di kalangan masyarakat. Banyak orang yang membagikan berita wacana politik ini di media sosial. Ada empat alasan yang menyebabkan wacana Pilkada DKI Jakarta menjadi trend topik pada tahun ini. Pertama, DKI Jakarta merupakan Ibukota Indonesia dan Indonesia selalu dimulai dari Jakarta. Jadi, apapun masalah yang terjadi di Jakarta akan menjadi polemik atau wacana yang selalu diperbincangkan. Kedua, Pilkada DKI Jakarta sarat dengan kepentingan politik yang terbagi menjadi dua kelompok besar, yaitu kelompok pemerintah dan oposisi atau yang berseberangan dengan pemerintah, masing-masing dengan partai-partai pendukungnya. Ketiga, salah satu pasangan calon terseret kasus SARA yang memicu terjadinya polemik berkepanjangan, tidak hanya di Jakarta, bahkan menyebar ke seluruh bagian Indonesia. Keempat, menurut pengamat politik, Pilkada DKI Jakarta menjadi barometer penentuan suhu politik di Indonesia (Agustina, 2017).

Wacana Pilkada DKI Jakarta tersebut memunculkan berbagai macam komentar masyarakat. Masyarakat menjadi "wartawan bebas" yang bebas mengeluarkan ide atau pendapatnya terkait wacana Pilkada DKI Jakarta. Semua media massa baik cetak, elektronik, maupun online juga memuat berita tentang Pilkada DKI Jakarta. Tidak hanya media massa, media sosial juga membahas isu Pilkada DKI Jakarta, yaitu berupa status dan komentar masyarakat.

Di Indonesia, salah satu media sosial yang masih banyak digunakan oleh masyarakat adalah facebook. Facebook merupakan media sosial yang paling banyak membagikan wacana politik Pilkada dibandingkan dengan media sosial lainya, seperti whatshap dan instagram. Facebook menjadi media sosial yang cenderung menjadi tempat interaksi terhadap berbagai informasi dan persoalan yang terjadi atau aktual di lingkungan masyarakat sehingga dapat menjadi pelampiasan masyarakat untuk mengungkapkan pendapat tentang permasalahan yang sedang hangat diperbincangkan, terutama masalah atau wacana yang berkaitan dengan sistem pemerintahan. Media sosial, seperti facebook, pada awalnya, cenderung berkaitan dengan persoalan pertemanan. Namun demikian, saat ini mulai banyak menyinggung ke ranah politik kekuasaan pemerintahan atau negara (Budiyono, 2016). Dalam konteks inilah, media sosial dapat menjadi salah satu alat, sarana, dan wadah untuk menampung aspirasi masyarakat sebagai bagian dari aktivitas politik (Alami, 2013).

Berdasarkan uraian tersebut, penelitian ini bertujuan untuk mendeskripsikan realisasi ideologi sekularisme dalam komentar masyarakat tentang wacana berita Pilkada DKI Jakarta di media sosial dilihat dari penggunaan kosakata dan struktur kalimat.

\section{METODE}

Penelitian ini menggunakan pendekatan kualitatif-deskriptif dan metode content analysis, serta berdasarkan teori analisis wacana kritis 
Norman Fairclough dalam tiga dimensi, yaitu: (1) analisis teks, (2) analisis praktik wacana, dan (3) analisis praktik sosial budaya (Fairclough, 2003). Namun dalam penelitian ini, ideologi dalam komentar masyarakat terhadap wacana berita Pilkada DKI Jakarta hanya disajikan dalam satu dimensi, yaitu analisis dari segi dimensi teks.

Instrumen utama dalam penelitian ini adalah peneliti sendiri. Untuk memudahkan dalam pengumpulan data, peneliti menggunakan alat bantu berupa media komputer untuk mengunduh data, lembar format inventaris data, lembar format identifikasi data, dan lembar format klasifikasi data. Lembar tersebut merupakan lembar yang digunakan untuk penganalisisan ideologi dalam wacana menurut Norman Fairclough.

Data penelitian ini adalah kata, frasa, dan kalimat serta gugusan kalimat yang mengandung representasi ideologi sekularisme dalam komentar masyarakat terhadap wacana Pilkada DKI Jakarta 2017. Sumber data penelitian ini adalah media sosial facebook yang memuat komentar masyarakat umum terhadap wacana berita Pilkada DKI Jakarta periode 2017, yaitu akun facebook@PilkadaDKI, FB AHY, FB Prabowo, FB Ahok, dan FB Djarot. Komentar masyarakat yang dipilih adalah komentar masyarakat terhadap wacana berita Pilkada DKI Jakarta periode 2017 yang dipublikasikan pada bulan Januari-April 2017. Hal ini dilakukan karena pada bulan tersebut merupakan masa diterbitkan wacana berita Pilkada DKI Jakarta dan banyak masyarakat yang memberikan komentar terhadap wacana berita Pilkada DKI Jakarta.

Teknik pengumpulan data dilakukan dengan menggunakan teknik snowball, yaitu mengambil dan mengumpulkan komentar masyarakat yang berkaitan dengan wacana berita Pilkada DKI Jakarta 2017 di media sosial facebook. Menurut Sugiyono (2010), teknik snowball adalah teknik pengumpulan sampel atau data dari sumber data, yang pada awalnya jumlahnya sedikit, lama-lama menjadi besar. Hal ini dilakukan karena dari jumlah sumber data yang sedikit itu belum mampu memberikan data yang memuaskan. Jadi, diperlukan tambahan sumber data yang lain agar didapatkan data penelitian yang lebih banyak, seperti bola salju yang menggelinding, lama-lama menjadi besar. Data dianggap telah memadai apabila telah sampai ke taraf redundancy (datanya telah jenuh dan jika ditam- bah data lagi, tidak memberikan informasi yang baru). Artinya, setelah mengambil data dari berbagai sumber data, tidak ditemukan lagi data yang baru.

Teknik pengumpulan data dalam penelitian ini terdiri atas tahapan-tahapan sebagai berikut. Pertama, membaca dan memahami komentar masyarakat terhadap wacana berita Pilkada DKI Jakarta di media sosial edisi bulan Januari-April 2017. Kedua, melakukan penginventarisasian dan pengklasifikasian data yang berupa komentar masyarakat terkait dengan wacana berita Pilkada DKI Jakarta di media sosial yang dijadikan objek penelitian. Ketiga, menandai data yang masuk ke dalam kriteria dan mencatat data yang telah ditandai tersebut ke dalam lembar kerja.

Selanjutnya, untuk penganalisisan data, digunakan metode analisis menurut Miles dan Huberman (1992) dalam tiga tahapan, yaitu (1) reduksi data, (2) penyajian data, dan (3) penarikan kesimpulan sesuai dengan prosedur langkah masing-masing tahapan. Pada tahap reduksi data.

Pada tahap reduksi, dilakukan tiga langkah berikut: (1) membaca data yang telah dikumpulkan secara keseluruhan, (2) menentukan komentar yang mengandung kosakata dan struktur kalimat yang mencerminkan ideologi sekularisme dalam komentar masyarakat terhadap wacana berita Pilkada DKI Jakarta di media sosial, dan (3) memisahkan komentar yang tidak merepresentasikan ideologi sekularisme ditinjau dari kosakata dan struktur kalimat.

\section{Tabel 1. Format Inventaris Data}

\begin{tabular}{cccccc}
\hline N & Komenta & Penu- & Judul & Tanggal & Sum \\
o & $\mathrm{r}$ & tur & Berita & $\begin{array}{c}\text { Publika } \\
\text {-ber }\end{array}$ & si \\
\hline
\end{tabular}

Pada tahap penyajian data, dilakukan langkah sebagai berikut. (1) Sebelum data diklasifikasikan, dilakukan pengkodean data terlebih dahulu. Pengkodean data dilakukan agar penulis mudah dalam pemeriksaan dan penarikan kesimpulan. Kode untuk struktur kosakata adalah KS, untuk struktur kalimat adalah SK. Pengodean juga berlaku untuk sumber data, misalnya sumber data dari situs @PilkubDKI2017 diberi kode PD. (2) Mengklasifikasikan data yang mengandung kosakata dan struktur 
kalimat yang mencerminkan ideologi sekularisme. (3) Data yang telah diklasifikasikan disajikan dalam bentuk tabel. Kemudian, agar mudah menganalisis data, data direduksi lagi penyajiannya ke dalam bentuk bagan untuk diuraikan dan dianalisis secara rinci.

Ada dua langkah yang dilakukan pada tahap penarikan kesimpulan, yaitu (1) mengecek dan mengulang kembali langkah-langkah analisis data dan (2) menarik kesimpulan tentang ideologi sekularisme dalam komentar masyarakat terhadap wacana Pilkada DKI Jakarta di media sosial ditinjau dari penggunaan kosakata dan struktur kalimat.

\section{HASIL DAN PEMBAHASAN}

\section{Hasil}

Berdasarkan hasil analisis data, ditemukan data yang merealisasikan ideologi sekularisme sebanyak 70 data. Dari 70 data tersebut ditemukan 55 data komentar masyarakat terhadap wacana berita Pilkada DKI Jakarta di media sosial yang merealisasikan ideologi sekularisme ditinjau dari pilihan kosakata dan 23 data ditinjau dari struktur kalimat, seperti tertera dalam tabel berikut.

Tabel 1. Ideologi Sekularisme Berdasarkan Pilihan Kosakata dan Struktur Kalimat

\begin{tabular}{|c|c|c|c|}
\hline $\begin{array}{ll}\mathbf{N} & \text { Asp } \\
\text { o } & \text { ek }\end{array}$ & $\begin{array}{l}\text { Temuan/ } \\
\text { Ideologi }\end{array}$ & $\begin{array}{l}\text { Jumlah } \\
\text { Data }\end{array}$ & $\begin{array}{l}\text { Persen- } \\
\text { tase }\end{array}$ \\
\hline 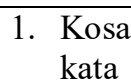 & Sekularisme & 55 & $70,51 \%$ \\
\hline \multirow[t]{3}{*}{$2 \quad \begin{array}{l}\text { Stru } \\
\text { ktur }\end{array}$} & $\begin{array}{l}\text { 1. Struktur } \\
\text { Kalimat } \\
\text { Aktif }\end{array}$ & 9 & $11,53 \%$ \\
\hline & $\begin{array}{l}\text { 2. Struktur } \\
\text { Kalimat } \\
\text { Pasif }\end{array}$ & 14 & $17,94 \%$ \\
\hline & Total & 78 & $100 \%$ \\
\hline
\end{tabular}

Jumlah data pada tabel 1 berbeda dengan jumlah data secara keseluruhan. Hal tersebut dikarenakan satu data dapat dianalisis dengan lebih dari satu struktur teks. Misalnya, satu data dapat dianalisis melalui dua struktur teks sekaligus, yaitu kosakata dan struktur kalimat. Hal demikian yang menyebabkan jumlah data yang ada di tabel 1 lebih banyak dibandingkan dengan jumlah data secara keseluruhan.

\section{Kosakata}

Komentar masyarakat terhadap waca-na berita Pilkada DKI Jakarta tahun 2017 di media sosial facebook mengandung represen-tasi ideologi sekularisme. Pengungkapan ideologi tersebut direalisasikan melalui kosakata yang digunakan oleh masyarakat pada saat berkomentar. Kosakata yang mengungkapkan ideologi sekularisme adalah kosakata yang tidak berkaitan dengan agama Islam dan cenderung menggunakan kata larangan seperti kata jangan. Kosakata tersebut dapat merealisasikan ideologi sekularisme jika dikaitkan dengan konteks. Selain itu, kosakata yang mengungkapkan ideologi sekularisme adalah kosakata yang bermakna mendukung salah satu pasangan calon dan memojokkan pasangan yang lain. Komentar masyarakat terhadap wacana berita Pilkada di media sosial yang merealisasikan ideologi sekularisme dilihat dari penggunaan kosakata ditemukan serjumlah 55 data, di antaranya dapat dilihat pada dua data berikut.

1) Jadilah pemilih cerdas yang objektif dan rasional berlandaskan hati nurani (MPM: 29/01/17).

2) Jangan pernah jadikan agama apapun buat topeng utk mencapai niat jdi penguasa, krn membawamu menjadi manusia arogansi, serakah, dan menjadikanmu lupa daratan, kehilangan akal (DRA: 07/02/17).

Dalam komentar (1), masyarakat merealisasikan ideologi sekularisme melalui kosakata pemilih cerdas, objektif, rasional, dan hati nurani. Pemilih cerdas ini ditujukan kepada masyarakat DKI Jakarta. Masyarakat menggunakan kosakata tersebut dengan maksud memengaruhi masyarakat agar cerdas dalam memilih kepala daerah. Pemilih yang cerdas adalah pemilih yang objektif dan rasional berlandaskan hati nurani. Hal tersebut mengindikasikan bahwa masyarakat tidak mempermasalahkan agama yang dianut oleh calon pemimpin. Masyarakat tidak mengait-ngaitkan masalah agama dengan masalah pemerintahan. Tidak penting bagi masyarakat calon pemimpin itu berasal dari agama dan etnis mana, yang penting adalah kerja nyata dari calon pemimpin tersebut.

Komentar (2) ditujukan kepada masyarakat DKI Jakarta yang mengikutsertakan agama 
ke dalam masalah pilkada. Dalam komentar tersebut, ideologi sekularisme direalisasikan melalui kosakata agama dan topeng. Kedua kosakata tersebut ditujukan kepada orang yang membawabawa agama ke dalam soal pemerintahan. Agama dianggap sebagai topeng. Artinya, agama dijadikan sebuah alat untuk memenangkan sebuah pertarungan pemilihan kepala daerah. Masyarakat yang berkomentar tersebut adalah salah satu masyarakat yang tidak mengaitkan agama ke dalam sistem yang berkaitan dengan pemerintahan. Masyarakat dengan tegas menya-takan bahwa jangan pernah jadikan agama apapun sebagai topeng untuk mencapai niat jadi penguasa karena hal demikian akan menjadikan manusia sebagai makhluk yang arogan dan serakah.

Selain dari dua data yang dipaparkan tersebut, ideologi sekularisme juga direalisasikan melalui kosakata metafora, seperti dalam contoh berikut.

3) Sebab paslon kiri dan kanan kena kalimat bijak seperti, "SERIGALA BERBULUH DOMBA", selalu berpenampilan dan beretika ibaratkan buluh Domba yg Putih, tetapi sesungguhnya SERIGALA! itulah sebabnya my Idol Mr. Ahk and Mr. Djr tersenyum dan tertawa sepanjang debate sesi 2. Bravo Mr. Ahk and Mr. Djr (CDT: 29/01/17).

Dalam komentar tersebut, digunakan kata metafora serigala berbulu domba. Metafora serigala berbulu domba berarti orang jahat seperti serigala, namun bersikap atau diluarnya tampak baik seperti bulu domba yang halus. Metafora tersebut ditujukan kepada pasangan calon gubernur DKI Jakarta nomor urut 1 dan 3. Kosakata tersebut membatasi pandangan pembaca bahwa paslon 1 dan 3 adalah orang yang selalu beretika dan bersikap seperti bulu domba yang halus dan putih padahal sifat yang ada pada kedua pasang calon tersebut jahat seperti serigala yang siap menerkam lawannya. Komentar tersebut merupakan salah satu bentuk dukungan kepada pasangan calon Gubernur DKI Jakarta nomor urut 2 dan salah satu bentuk ketidaksukaan maysarakat kepada pasangan calon urut nomor 1 dan 3. Jika dikaitkan dengan ideologi berdasarkan hubungan agama dengan sistem pemerintahan, dapat diketahui bahwa masyarakat yang berinisial CDT menganut pandangan atau representasi ideologi sekularisme.
Selain kosakata tersebut, ideologi sekularisme dalam komentar masyarakat terhadap wacana berita Pilkada DKI Jakarta direalisasikan melalui kosakata mati kutu, rakyat cerdas, serigala berbulu domba, kerja nyata, janji-janji palsu, kebodohan, mabuk jabatan, menjual agama, pelayan masyarakat, korban politik, penghayal tingkat tinggi, dasar munafik, licik dan culas, jangan bawa-bawa agama, rakyat makin cerdas, gambaran orang munafik, visi misinya nggak jelas, dalang dan pemicu keributan, kebanyakan ngayal, program orisinil, seonggok jabatan, dasar calon odong-odong, pendongeng, belum berpengalaman, realistis, jelas dan terbukti, bego dan bodoh, isu agama, program retorika, tukang fitnah, kinerja, dsb.

\section{Struktur Kalimat}

Komentar masyarakat terhadap wacana berita Pilkada DKI Jakarta tahun 2017 di media sosial facebook mengandung representasi ideologi sekularisme yang direalisasikan melalui struktur kalimat yang dominan menampilkan pelaku dalam teks. Orang atau peristiwa yang dominan ditampilkan sebagai bentuk tindakan yang ditandai dengan struktur kalimat aktif. Setelah dilakukan analisis data, ditemukan dua struktur kalimat yang digunakan masyarakat dalam komentar terhadap wacana berita Pilkada DKI Jakarta 2017 yang mengungkapkan ideologi sekularisme, yaitu (1) struktur kalimat aktif dan (2) struktur kalimat pasif. Akan tetapi, struktur kalimat yang dominan digunakan adalah struktur kalimat aktif.

\section{Kalimat Aktif}

Komentar masyarakat yang menggunakan strategi struktur kalimat aktif berjumlah sebanyak 14 data. Untuk lebih jelasnya mengenai komentar tersebut, dapat dilihat pada kutipan utuh data berikut.

4) ...rakyat cerdas pasti memilih gubernur yang cerdas pula... (TW: 29/ 01/17).

5) ... di setiap debat calon yang lain hanya memperlihatkan kebodohannya dengan gaya kekinian memakai bahaas Inggris tp bikin ketawa ngakak persis anak tk yg sedang belajar bhs inggris my name is Agus.. Itu kata2 yg bikin ngakak abis (FNAN:31/01/17). 
Komentar (4) menampilkan suatu peristiwa sebagai suatu tindakan yang ditandai dengan digunakan kata kerja (verba) aktif, yaitu memilih dalam klausa rakyat cerdas pasti memilih gubernur yang cerdas pula... Dari klausa tersebut dapat dilihat dengan jelas bahwa verba transitif memilih membutuhkan subjek dan objek, yaitu rakyat cerdas dan gubernur yang cerdas pula. Tidak ada yang disembunyikan dalam teks, subjek ditonjolkan dalam teks untuk meyakinkan pembaca, sekaligus menyindir warga DKI Jakarta bahwa rakyat cerdas adalah rakyat yang memilih gubernur yang cerdas, yaitu Ahk. Jika rakyat tidak memilih Ahk, berarti rakyat tersebut bukanlah rakyat yang cerdas dan matahati mereka telah dibutakan oleh uang atau amplop. Jika dikaitkan dengan konteks pada saat itu, TW tidak mempermasalahkan kasus penistaan agama yang disandang Ahk. Akan tetapi, TW lebih melihat dari sisi baik Ahk, yaitu sebagai pemimpin yang mempunyai integritas.

Selanjutnya, komentar (5) juga direalisasikan melalui struktur kalamat aktif yang ditandai dengan verba memperlihatkan dalam klausa di setiap debat calon yang lain hanya memperlihatkan kebodohannya. Pelaku seolaholah dipojokkan dalam teks. Pelaku ditonjolkan dalam teks dengan maksud untuk memperlihatkan kekurangan dari paslon lain, yaitu paslon nomor 1 dan 3. Dengan digunakan struktur kalimat aktif, pembaca dapat menangkap secara cepat maksud yang disampaikan oleh masyarakat, yaitu ingin menunjukkan kekurangan paslon nomor 1 dan 3, dan ingin memperlihatkan kelebihan paslon nomor 2. Hal ini, bertujuan agar masyarakat setuju dengan pendapatnya untuk memilih paslon nomor 2 sebagai Gubernur DKI Jakarta. Dari uraian tersebut, dapat diketahui bahwa masyarakat tidak pernah menyangkut pautkan masalah agama ke dalam komentarnya.

\section{Kalimat Pasif}

Komentar masyarakat yang menggunakan strategi struktur kalimat pasif yang merealisasikan ideologi agamaisme dapat dilihat pada kutipan (6) dan (7). Dua data tersebut memanfaatkan kalimat pasif untuk merepresentasikan ideologi.

6) Mari Jakarta kita dukung perjuangan Ahok-Djarot. Jangan mau kita dibodohi dan dipecahbelahkan (NR: 05/04/17).
7) Strategi menghalalkan segala cara, yang penting Ahok Djarot dapat dikalahkan. Di zaman majapahit saja tidak seperti ini, kok di zaman digital justru tidak beradat (SC: 16/04/17).

Komentar (6) dan (7) merealisasikan ideologi sekularisme dengan menggunakan struktur kalimat pasif. Komentar (6) menampilkan suatu peristiwa ke dalam bentuk keadaan dengan dua klausa pasif yang dengan makna ajakan Mari Jakarta dan Jangan mau kita dibodohi dan dipecahbelahkan. Dalam kalimat tersebut tidak ditampilkan pelaku, siapa yang membodohi dan siapa yang memecahbelahkan. Akan tetapi, yang diton-jolkan dalam teks tersebut adalah objek atau sasaran, yaitu Jakarta dan kita yang berarti 'seluruh masyarakat Jakarta'. Penggunaan pronominal kita sebagai Objek ditonjolkan dengan maksud agar masyarakat terlihat teraniaya oleh pembaca karena telah dibodohi dan dipecahbelahkan oleh pihak yang berlawanan dengan Ahok. Komentar tersebut adalah bentuk pembelaaan kepada Ahok beserta pendukungnya. Jika dikaitkan dengan konteksnya, masyarakat yang dimaksud adalah yang tidak terpengaruh dengan latar belakang agama calon pemimpin.

Dalam Komentar (7) digunakan struktur kalimat pasif, yang penting Ahok Djarot dikalahkan. Dalam teks tersebut pelaku tidak ditampilkan, tetapi objek atau sasaran ditampilkan. Dengan menampilkan objek, orang dapat menafsirkan bahwa objek adalah korban. Korban dari orang yang mengalahkan Ahok-Djarot dengan strategi menghalalkan segala cara. Kemudian, masyarakat juga menggunakan istilah beradat dalam teks. Keadaan tersebut ditujukan kepada orang/pihak yang tidak lagi menggunakan etika dalam berkompetisi sehingga menghalalkan segala cara untuk mengalahkan AhokDjarot. Berdasarkan komentar tersebut, dapat diketahui bahwa komentar ditujukan kepada orang yang berlawanan dengan Ahok dan dimaksudkan sebagai pembelaan terhadap pasangan AhokDjarot. Dalam komentar tersebut tidak ada sedikitpun disinggung permasalahan yang berkaitan dengan agama.

\section{Pembahasan}

Komentar masyarakat terhadap wacana berita Pilkada DKI Jakarta tahun 2017 di media 
sosial salah satunya didominasi oleh representasi ideologi sekularisme. Sekularisme merupakan paham yang memisahkan antara agama dengan sistem pemerintahan (Hurd, 2004; Tiwary, 2017). Ternyata, setelah dilakukan analisis data ditemukan representasi ideologi sekularisme sebanyak 70 data. Dari hasil penelitian terdahulu juga banyak ditemukan masyarakat yang tidak mengikut-sertakan masalah agama ke dalam hal yang berkaitan dengan kepemimpinan (Altwajri, 1997: 120; Abdulsyani, 2012: 178; Susanto, 2013: 41). Bagi masyarakat sekular, agama tidak penting dalam memilih pemimpin, yang penting adalah bukti nyata dari kinerjanya.

Munculnya ideologi tersebut disebabkan oleh panasnya situasi politik pada saat itu. Pilkada DKI Jakarta 2017 memang menjadi trend topik yang hangat diperbincangkan. Banyak wacana berita politik Pilkada muncul di berbagai media, tidak hanya di media massa, tetapi juga di media sosial, terutama di facebook. Panasnya suasana politik pada saat itu disebabkan oleh salah satu paslon Pilkada DKI Jakarta terseret isu SARA. Hal demikian yang menyebabkan munculnya pro dan kontra terhadap pemilihan paslon tersebut. Masya-rakat melampiaskan semua emosi melalui komentar terhadap wacana politik yang dibagikan ke akun facebook. Banyak masya-rakat yang mengaitngaitkan agama pada saat memilih pemimpin DKI. Masyarakat menolak salah satu paslon yang terseret kasus isu SARA dan menganggap bahwa yang pantas menjadi pemimpin DKI Jakarta adalah orang yang seiman (muslim). Namun demikian, banyak juga masyarakat yang tidak mengaitngaitkan aga-ma pada saat memilih pemimpin DKI Jakarta. Masyarakat tidak melihat agama, tetapi melihat kinerja, visi dan misi dari paslon tersebut. Itu semua diungkapkan masyarakat melalui komentar terhadap wacana politik yang dibagikan di akun media sosial facebook. Masyarakat berbuat demikian tentu dipengaruhi oleh faktor tertentu, salah satunya adalah faktor ideologi, yaitu representasi ideologi sekularisme.

Representasi ideologi sekularisme dalam komentar masyarakat terhadap wacana berita Pilkada DKI Jakarta tahun 2017 di media sosial dilihat dari pilihan kosakataa dan struktur kalimatseperti berikut ini.

\section{Representasi Ideologi Sekularisme Dilihat dari Kosakata}

Dilihat dari penggunaan kosakata ditemukan data yang merepresentasikan ideologi sekularisme sebanyak 55 data. Dalam analisis wacana kritis, ideologi dapat diungkapkan dalam teks yang dilihat melalui pilihan kosakata (Asghar, 2014; Shahsvar \& Naderi, 2015; Widyawari \& Zulaeha, 2016; Faghih \& Moghiti, 2017). Pilihan kosakata juga dapat dilihat dari pemakaian metafora yang dipakai. Menurut Fairlough (Eriyanto, 2009: 292), pilihan pada metafora merupakan kunci bagaimana realitas ditampilkan dan dibedakan dengan yang lain. Metafora bukan hanya persoalan keindahan literer karena bisa menentukan apakah realitas itu dimaknai dan dikategorikan sebagai positif ataukah negatif.

Pilihan kosakata yang dipakai dalam teks komentar berhubungan dengan bagaimana peristiwa, seseorang, kelompok, atau kegiatan tertentu dikategorikan dalam suatu set tertentu (Eriyanto, 2009: 290). Kosakata sangat menentukan maksud yang ingin disampaikan oleh penulis karena berhubungan dengan pertanyaan bagaimana realitas ditandakan dalam bahasa dan cara bahasa itu memunculkan realitas bentukan tertentu.

Dalam konteksnya, kosakata yang merepresentasikan ideologi sekularisme dalam komentar masyarakat terhadap wacana berita pilkada DKI Jakarta adalah kosakata yang tidak berkaitan dengan agama Islam. Kosakata tersebut digunakan bertujuan untuk mengungkapkan kejelekan atau kelemahan yang dimiliki paslon Ans-Snd dan menampilkan kelebihan atau keunggulan paslon Ahk-Djarot.

\section{Representasi Ideologi Sekularisme Dilihat dari Struktur Kalimat Aktif dan Pasif}

Dilihat dari penggunaan struktur kalimat ditemukan data yang merepresentasikan ideologi sekularisme sebanyak 23 data. Representasi ideologi sekularisme dalam komentar masyarakat juga dapat diungkapkan dengan melihat struktur kalimat. Setelah dilakukan analisis data, ditemukan dua struktur kalimat yang digunakan masyarakat pada saat berkomentar terhadap wacana berita Pilkada DKI Jakarta di media sosial, yaitu struktur kalimat aktif dan pasif. 
Struktur tersebut bukanlah persoalan teknis semata, tetapi ada maksud yang dapat diungkapkan di balik struktur tersebut. Dengan menampilkan aktor secara jelas dalam komentar tersebut, pembaca bisa memaknai bahwa AnsSnd adalah pasangan calon gubernur yang tidak baik, pendusta karena telah membohongi masyarakat. Pernyataan tersebut sejalan dengan pendapat Eriyanto (2009: 293) bahwa bentukbentuk yang berbeda bukan hanya persoalan tata bahasa tetapi makna yang diterima khalayak juga berbeda-beda. Suatu peristiwa, tindakan, atau aktor dapat ditampilkan secara berbeda dengan menggunakan susunan tata bahasa yang berbeda pula.

Struktur kalimat yang merepresentasikan ideologi sekularisme adalah struktur kalimat yang dominan menampilkan pelaku dalam teks. Orang atau peristiwa dominan ditampilkan sebagai bentuk tindakan yang ditandai dengan struktur kalimat aktif. Dalam hal ini, masyarakat yang menggunakan struktur kalimat aktif untuk merepresen-tasikan ideologi sekularisme adalah masyara-kat yang berpihak kepada pasangan calon Ahk-Djr dan tidak suka kepada pasangan Ans-Snd. Oleh karena itu, pilihan pada struktur kalimat aktif bertujuan untuk memojokkan pelaku, yaitu Ans-Snd.

Berdasarkan uraian tersebut, dapat diketahui bahwa komentar masyarakat terhadap wacana Pilkada DKI Jakarta tahun 2017 yang merepresentasikan ideologi sekularisme, baik dilihat dari penggunaan kosakata maupun struktur kalimat merupakan salah satu bentuk dukungan atau keberpihakan masyarakat kepada pasangan gubernur Ahk-Djr dan bentuk ketidaksukaan masyarakat kepada pasangan Ans-Snd. Masyarakat berpihak ke Ahk-Djr karena kinerja Ahk yang sudah teruji dan terbukti untuk DKI pada pemerintahannya yang sedang berjalan.

Hasil penelitian ini relevan dengan hasil penelitian yang dilakukan oleh peneliti terdahulu, di antaranya Rahimi \& Riasati (2011), Ahmadi \& Asl (2013), Asghar (2014), Ahmed (2014), Faris \& Paramasivam (2016), Ramanathan \& Hoon (2016), dan Mohammadi (2017). Rahimi \& Riasati (2011) yang meneliti tentang ideologi dalam wacana Driven di Iran. Dari penelitian tersebut, diketahui bahwa analisis wacana kritis dapat mengungkapkan maksud yang tersembunyi dan ideologi yang ada dibalik bahasa yang digunakan dalam teks. Ahmadi \& Asl (2013), meneliti tentang editorial dan ideologi dalam surat kabar di Iran. Hasil penelitian tersebut menunjukkan bahwa bahasa yang digunakan dalam editorial surat kabar di Iran mengandung ideologi politik. Ahmed (2014) meneliti tentang pidato Perdana Menteri mengenai kendaraan udara berbahasa. Penelitian ini bertujuan untuk menemukan ideologi tersembunyi di balik kata-kata yang digunakan dalam bahasa melalui CDA. Asghar (2014) meneliti tentang analisis wacana kritis terhadap perspektif ideologis dalam wacana media. Hasil penelitan tersebut menunjukkan bahwa identitas sosial dan budaya berperan dalam membentuk ideologi surat kabar.

Faris \& Paramasivam (2016) melakukan penelitian tentang ideologi dalam wacana Nelson Mandela di Mandela. Dari penelitian tersebut, diketahui bahwa analisis wacana kritis dapat menjelajahi ideologi fundamental yang tertanam dalam wacana Mandela. Ramanathan \& Hoon (2016) juga melakukan penelitian tentang ideologi dalam wacana dengan menggunakan analisis wacana kritis di Malaysia. Dari penelitian tersebut, diketahui bahwa analisis wacana kritis memainkan peran penting dalam mengungkap ideologi yang tersembunyi dalam sebuah wacana. Selanjutnya, Mohammadi (2017) melakukan penelitian tentang analisis wacana kritis bahasa yang digunakan Donald Trump pada saat kampanye di Amerika Serikat. Berdasarkan penelitian tersebut, diketahui bahwa bahasa yang digunakan Donald Trump pada saat kampanye mengandung ideologi tertentu.

Hasil yang dilakukan oleh penelitian terdahulu mendukung hasil penilitian ini. Secara umum, dapat diketahui bahwa terdapat ideologi tertentu dalam teks. Hal tersebut diketahui dari bahasa yang digunakan dalam teks. Pilihan kosakata yang digunakan dalam teks wacana dapat mengandung representasi ideologi tertentu (Asghar, 2014).

Penelitian ini berbeda dengan penelitian sebelumya. Penelitian sebelumnya cenderung melihat ideologi wartawan dan media yang menaunginya seperti surat kabar, sementara penelitian ini meneliti ideologi masing-masing masyarakat yang sifatnya personal di media sosial dan bagaimana ideologi tersebut direalisasikan. Setiap masyarakat yang berkomentar terkait dengan wacana politik Pilkada dikaji ideologi apa yang memengaruhi masyarakat tersebut sehingga berkomentar demikian. Teks yang ada di media massa berbeda dengan teks yang ada di 
media sosial. Wacana atau teks di media massa masih di bawah naungan media dan cenderung formal, sementara di media sosial seperti di facebook, masyarakat bebas menulis teks atau berkomentar dan tidak bersifat formal.

Berdasarkan hasil penelitian dan pembahasan, penelitian ini memiliki implikasi secara teoretis dan praktis. Implikasi teoretis, penelitian ini dapat menambah pengetahuan pembaca, terutama mahasiswa mengenai penelitian analisis wacana kritis. Implikasi praktis penelitian ini adalah dalam dunia pendidikan. Penelitian ini dapat dijadikan sebagai pedoman bahan pembelajaran memahami isi teks berita oleh guru. Guru bisa mengajak siswa lebih kritis dalam memaknai isi berita atau komentar masyarakat umum terhadap sebuah wacana berita di media sosial. Bagi pembaca, hasil penelitian ini diharapkan dapat meningkatkan daya kritis pembaca dalam memaknai makna wacana dan ideologi dalam komentar masyarakat umum terhadap wacana suatu berita di media sosial.

\section{SIMPULAN}

Terdapat realisasi ideologi sekularisme dalam komentar masyarakat terhadap wacana berita Pilkada DKI Jakarta 2017 di media sosial yang direalisasikan melalui kosakata yang merepresentasikan paham tidak perlu mengaitkan agama dalam menentukan pilihan terhadap pemimpin DKI. Ada beberapa kosakata yang digunakan kaitannya dengan pilkada DKI. Kosakata tersebut diidentifikasi, di antaranya: pemilih cerdas, objektif, rasional, hati nurani, mati kutu, rakyat cerdas, serigala berbulu domba, kerja nyata, janji-janji palsu, kebodohan, mabuk jabatan, menjual agama, pelayan masyarakat, korban politik, penghayal tingkat tinggi, dasar munafik, licik dan culas, jangan bawa-bawa agama, rakyat makin cerdas, gambaran orang munafik, visi misinya nggak jelas, dalang dan

\section{DAFTAR RUJUKAN}

Abdulsyani. 2012. Sosiologi Skematika, Teori dan Terapan. Jakarta: PT Bumi Aksara.

Agustina. 2017. Kekerasan verbal dalam pilkada DKI: Mengungkap Tingkat Kesantunan Masyarakat Berwacana Politik. Padang: UNP. pemicu keributan, kebanyakan ngayal, program orisinil, seonggok jabatan, dasar calon odongodong, pendongeng, belum berpengalaman, realistis, jelas dan terbukti, bego dan bodoh, isu agama, program retorika, tukang fitnah, kinerja, $d s b$. Semua kosakata tersebut digunakan bertujuan untuk menampilkan kejelekan dan kelemahan paslon Ans-Snd serta memberikan citra buruk kepada paslon tersebut.

Ideologi sekularisme direalisasikan masyarakat dalam komentarnya tentang berita Pilkada DKI melalui penggunaan dua struktur kalimat. Pertama, penggunaan struktur kalimat aktif oleh masyarakat dalam komentarnya bertujuan untuk mengunggulkan atau menon-jolkan kebaikan-kebaikan pelaku (paslon) yang disukainya dan struktur kalimat aktif juga digunakan untuk sebaliknya, yaitu memojokkan atau menampilkan kejelekan-kejelekan pelaku (paslon) yang tidak disukai-nya. Kedua, kalimat pasif digunakan oleh masyarakat dalam komentarnya tentang berita Pilkada DKI bertujuan untuk mengunggulkan sasaran (paslon) dan menyembunyikan pelaku dari kejelekan-kejelekannya dan sebaliknya struktur kalimat pasif digunakan juga untuk memojokkan sasaran (paslon) dan menyembunyikan pelaku.

Dapat disimpulkan bahwa ideologi dalam wacana dapat diungkapkan melalui pilihan kosakata dan struktur kalimat dalam teks melalui analisis wacana kritis, baik dalam teks media massa sebagai perwakilan institusinya, maupun dalam teks (komentar) individu di media sosial sebagai pewakilan masyarakatnya.

\section{UCAPAN TERIMA KASIH}

Penulis mengucapkan terima kasih kepada mitra bestari (reviewers) yang telah memberikan saran, kritik, dan komentar terhadap artikel ini. Respon yang diberikan mitra bestari sangat membantu penulis.
Ahmadi, H. dan Asl, E. S. 2013. Editorials and Ideologies. International Journal of Culture Sains dan Olahraga, 1 (4): 11-21.

Ahmed, S. 2014. Critical discourse analysis of primer minister's speeches on harmful aerial vehicles (drones). International Journal of Language and Linguistics, 1 (2): 37-44. 
Alami, A. N. 2013. Menakar Kekuatan Media Sosial Menjelang Pemilu 2014. Jurnal Penelitian Politik, 10 (1): 85-99.

Ali, M. K. \& Nordin, M. Z. F. 2016. Linguistic Legitimation of Political Events in Newspaper Discourse Advances in Language and Literary Studies, 7 (4): 76-83.

Altwajri, A.O. 1997. Islam, Barat, dan Kebebsan Akademis. Yogyakarta: Titian Ilahi Press.

Asghar, J. (2014). Language Power and Ideology in Commercial Discourse: A Prologue to Critical Dicourse Analysis for Neophyte Analysts. Academic Journal of Interdisciplinary Studies, 3 (4): 252-262.

Asghar, J. 2014. Words Speak Louder than Actions: A Critical Analysis of Ideological Perspectives in Media Discourse. International Journal of Humanities and Social Science, 4 (5): 169-181.

Budiyono. 2016. Media Sosial dan Komunikasi Politik: Media Sosial sebagai Komunikasi Politik Menjelang Pilkada DKI Jakarta 2017. Jurnal Komunikasi. 11 (1): 47-62.

Bukhari, N. H. S. dan Xiaoyang, W. 2013. Critical Discourse Analysis and Educational Research. Journal of Research \& Method in Education (IOSR-JRME), 3 (1): 9-17.

Eriyanto. 2009. Analisis wacana pengantar analisis teks media. Yogyakarta: LkiS.

Faghih, E. \& Moghiti, R. 2017. Persian Renderings of English Conceptual Discourse Patterns: A Case Study of Animal Farm. International Journal of Comparative Literature \& Translation. Volume 5 (3): 55-66.

Fairclough, N. 2003. Language and Power: Relasi Bahasa, Kekuasaan, dan Ideologi. Malang: Boyan Publishing.

Faris, A. A. dan Paramasivam, S. 2016. Ideologies in Mandela's No Easy Walk to Freedom. International Journal of Applied Linguistics \& English Literature, 5 (5): 49-61.

Hurd, E. S. 2004. The Political Authority of Secularism in International Relations. European Journal of International Relation, 10 (2): 235262.

Miles, M.B. dan Huberman, A.M. 1992. Analisis data kualitatif. Terj. Tjetjep Rohendi Rohidi. Jakarta: University Indonesia Perss.

Mohammadi, M. \& Javadi, J. 2017. A Critical Discourse Analysis of Donald Trump's Language Usein US Presidential Campaign,
2016. International Journal of Applied Linguistics \& English Literature, 6 (5): 1-10.

Rahimi, F. dan Riasati, M. J. 2011. Critical Discourse Analysis: Scrutinizing Ideologically-Driven Discourses. International Journal of Humanities and Social Science, 1 (16): 107112.

Ramanathan, R. dan Hoon, T. B. 2016. Application of Critical Discourse Analysis in Media Discourse Studies. The Southeast Asian Journal of English Language Studies, 21 (2).

Sideeg, A. I. A. 2015. Traces of Ideology in Translating the Qurān into English: A Critical Discourse Analysis of Six Cases Across Twenty Versions. International Journal of Applied Linguistics \& English Literature, 4 (5): 214-226.

Shahsavar, Z. \& Naderi, M. S. H. 2015. Investigating the Influence of Ideology on Translation: A Critical Discourse Analysis of "ATale of Two Cities" and Its Persian Translations. International Journal of English Language Translation Studies. Published on: 07/03/2015.

Sobur, A. 2016. Analisis Teks Media: Suatu Pengantar untuk Analisis Wacana, Analisis Semiotik, dan Analisis Framing. Bandung: Remaja Rosdakarya.

Sugiyono. 2010. Metode Penelitian Pendidikan. Bandung: Alfabeta.

Susanto, A. 2013. Filsafat Ilmu: Suatu Kajian dalam Dimensi Ontologis, Epistimologis, dan Aksiologis. Jakarta: Bumi Aksara.

Syam, F. 2010. Pemikiran Politik Barat: Sejarah, Filsafat, Ideologi, dan Pengaruhnya tehadap Dunia ke-3. Jakarta: PT Bumi Aksara.

Tiwary, P. 2017. The Ideology of Secularism in Indian Constitution. International Journal of Humanities and Social Science Research, 3 (2): 43-50.

Usfinit, Y., Suprojo, A., \& Setyawan, D. 2014. Perspektif Partisipasi Politik Masyarakat pada Pemilihan Kepala Daerah (pilkada) Kota Malang. Jurnal Ilmu Sosial dan Ilmu Politik 3 (1): $38-45$.

Vahid, H. 2012. The Power Behind Images: Advertisement Discourse in Focus. International Journal of Linguistics, 4 (4): 3648.

Widyawari, C. P. G. dan Zulaeha, I. 2016. Representasi Ideologi dalam Tuturan Santun para Pejabat Negara pada Talk Show Mata Najwa. Jurnal Pendidikan Bahasa dan Sastra Indonesia Seloka 5 (1): 1-11. 